\title{
ВПЛИВ ЧОТИРИХЛОРИСТОГО ВУГЛЕЦЮ НА СТАН ВІЛЬНОРАДИКАЛЬНИХ ПРОЦЕСІВ ОРГАНІЗМУ ЩУРІВ ТА МОРФОЛОГІЧНІ ЗМІНИ У ТОВСТІЙ КИШЦІ
}

Вступ. Підвищене надходження галенових сполук в організм людини і тварин може спровокувати розвиток функціональних порушень та патологічних змін органів травної системи, зокрема товстої кишки.

Мета дослідження - оцінити стан вільнорадикальних процесів організму та морфологічні зміни у товстій кишці піддослідних тварин при токсичному впливі на них чотирихлористого вуглецю (CCl).

Методи дослідження. Дослідження виконано на 44 білих щурах-самцях масою 180-200 г, яких поділили на чотири групи: 1-ша (контрольна) - практично здорові тварини; 2-4 - щури зі змодельованим токсичним ураженням $\mathrm{CCl}_{4}$. Чотирихлористий вуглець вводили внутрішньошлунково у вигляді 50,0 \% олійного розчину з розрахунку 0,2 мл чистої речовини на 100 г маси тіла тварини. Інтенсивність вільнорадикальних процесів оцінювали за рівнем малонового діальдегіду та дієнових кон'югатів, які визначали за допомогою спектрофотометричних методик, стан антиоксидантної системи - за активністю каталази у крові. За загальноприйнятою методикою виготовляли гістологічні препарати, для якісного $і$ морфометричного аналізу яких використовували систему візуального аналізу зображення із застосуванням відеокамери Vision Color CCD та програму Inter Video Win DVR UTHSCSA Image Tool.

Результати й обговорення. Інтоксикація тварин $\mathrm{CCl}_{4}$ супроводжувалась активацією вільнорадикального окиснення ліпідів, про що свідчило збільшення в сироватці крові щурів вмісту як малонового діальдегіду, так і дієнових кон'югатів протягом усього експерименту, причому максимальну концентрацію малонового діальдегіду спостерігали на 7-му добу після отруєння. Під впливом $\mathrm{CCl}_{4}$ активність каталази в сироватці крові зросла на 2-гу, 7-му та 14-ту доби експерименту в 1,3, 1,2 і 2,4 раза відповідно. Морфометричними методами виявили значну структурну перебудову слизової оболонки, підслизової основи, м'язової та серозної оболонок товстої кишки, що супроводжувалась вираженими судинними розладами, альтеративними, інфрільтративними процесами і змінами морфометричних параметрів структур стінки товстої кишки на тканинному й органному рівнях.

Висновки. При ураженні $\mathrm{CCl}_{4}$ відбуваються суттєва активізація процесів вільнорадикального окиснення, підвищене накопичення в крові токсичних продуктів ПОЛ та послаблення орерментативних систем антиоксидантного захисту. Встановлено значну структурну перебудову слизової оболонки, підслизової основи, м'язової та серозної оболонок товстої кишки в динаміці експерименту.

КЛЮЧОВІ СЛОВА: чотирихлористий вуглець; вільнорадикальне окиснення; морфологічні зміни; стінка товстої кишки.

ВСТУП. За даними Всесвітньої організації охорони здоров'я, одними з найбільш поширених у світі $€$ хвороби органів травлення, які займають третє місце після захворювань серцево-судинної системи та онкологічних патологій $[1,2]$. Усі органи шлунково-кишкового тракту являють собою єдину фрункціональну систему, ланки якої тісно пов'язані між собою нейрогуморальною, імунною та ендокринною регуляцією. Складні, багатогранні й не до кінця вивчені зв'язки існують між

() А. М. Пришляк, С. І. Яворська, Т. К. Головата, Б. Я. Ремінецький, 2017. органами шлунково-кишкового тракту [3, 4]. На сьогодні спостерігають зростання частоти уражень товстої кишки. Особливо багато нез'ясованих питань виникає при вивченні поєднаних ушкоджень органів травлення на різних рівнях їх структурної організації $[5,6]$. Усе це визначає актуальність і важливість вивчення патологій товстої кишки токсичного генезу та необхідність їх детального й об'єктивного дослідження.

Мета дослідження - оцінити стан вільнорадикальних процесів організму та морфологічні зміни у товстій кишці піддослідних тварин при 
токсичному впливі на них чотирихлористого вуглецю $\left(\mathrm{CCl}_{4}\right)$.

МЕТОДИ ДОСЛІДЖЕННЯ. КомпЛЕксом біохімічних, морфологічних (гістологічний, морфометричний) і статистичних методів досліджено сироватку крові та товсту кишку 44 білих щурів-самців, яких поділили на чотири групи: 1-ша (контрольна) - 10 піддослідних практично здорових тварин, які перебували у звичайних умовах віварію; 2-га - 12 білих щурів із змодельованим токсичним гепатитом, евтаназію яких здійснювали на 2-гу добу від початку експерименту; 3-тя - 11 піддослідних тварин із токсичним гепатитом - на 7-му добу експерименту; 4-та - 11 білих щурів із токсичним гепатитом - через 14 діб від початку досліду. Досліди на експериментальних білих щурах проводили відповідно до Загальних етичних принципів експериментів на тваринах, ухвалених на Першому національному конгресі з біоетики (Київ, 2001) та узгоджених 3 положеннями Європейської конвенції про захист хребетних тварин, що використовуються для дослідних та інших наукових цілей (Страсбург, 1986). Токсичний гепатит моделювали шляхом внутрішньошлункового введення 50,0 \% олійного розчину чотирихлористого вуглецю в дозі 0,2 мл чистої речовини на 100 г маси тіла тварини. Ця доза викликає гострий гепатит [7]. Евтаназію піддослідних тварин здійснювали за допомогою кровопускання за умов тіопентал-натрієвого наркозу. Інтенсивність процесів пероксидного окиснення ліпідів (ПОЛ) оцінювали за рівнем малонового діальдегіду (МДА) та дієнових кон'югатів (ДК). Рівень МДА та ДК визначали за допомогою спектрофотометричних методик [8]. Стан антиоксидантної системи оцінювали за активністю каталази у крові [9]. Для морорологічних досліджень вирізані шматочки товстої кишки фріксували в 10,0 \% розчині нейтрального формаліну. Проводили через етилові спирти зростаючої концентрації і поміщали в парафрін. Мікротомні зрізи товщиною 5-8 мкм після депарафрінізації забарвлювали гематоксилін-еозином за ван Гізон, Маллорі, Вейгертом. Морфометричні дослідження проводили за методикою Г. Г. Ав- танділова в модифрікації М. С. Гнатюка $[10,11]$. Для якісного і кількісного аналізу гістологічних препаратів використовували систему візуального аналізу зображення із застосуванням відеокамери Vision Color CCD і програмy Inter Video Win DVR UTHSCSA Image Tool.

РЕЗУЛЬТАТИ Й ОБГОВОРЕННЯ. ІНТЕНСИВність процесів ліпопероксидації оцінювали за вмістом малонового діальдегіду та дієнових кон'югатів. Результати досліджень показали, що інтоксикація тварин $\mathrm{CCl}_{4}$ супроводжувалась активацією вільнорадикального окиснення ліпідів, про що свідчило збільшення в сироватці крові щурів вмісту як МДА, так і ДК протягом усього експерименту, причому максимальну концентрацію малонового діальдегіду спостерігали на 7-му добу після отруєння (табл.).

У цей термін вміст МДА зріс у сироватці крові на 301,4 \% (р<0,001). Вагомою причиною активації вільнорадикальних процесів за даних патологічних умов могло бути порушення в системі антиоксидантного захисту організму. Одним з основних антиоксидантних ферментів $€$ каталаза, яка знешкоджує пероксид водню [9]. В результаті проведених досліджень встановлено, що під впливом $\mathrm{CCl}_{4}$ активність каталази в сироватці крові зросла на 2-гу, 7-му та 14-ту доби експерименту в 1,3, 1,2 і 2,4 раза відповідно порівняно з контрольною групою тварин. Підвищення активності каталази є компенсаторною реакцією організму на дію токсичного агента, проте динаміка зростання вмісту продуктів ПОЛ значно перевищувала збільшення активності каталази в крові піддослідних тварин (див. табл.).

При гістологічному вивченні товстої кишки інтактних тварин чітко вирізнялися всі оболонки даного органа (слизова, м'язова та серозна оболонки і підслизова основа). Структура стінки неураженої товстої кишки була звичайною. Встановлено, що чотирихлористий вуглець викликав патологічні зміни в стінці досліджуваного органа на фроні гострого гепатиту, які проявлялися у всі терміни досліду. Морфометрично встановлено, що товщина слизової оболонки товстої кишки на 2-гу добу проведеного експерименту збільши-

Таблиця - Біохімічні показники сироватки крові білих щурів у нормі та за умов тетрахлорметанового гепатиту різної тривалості (M士m)

\begin{tabular}{|c|c|c|c|c|}
\hline \multirow{3}{*}{ Показник } & \multicolumn{4}{|c|}{ Група тварин } \\
\hline & \multirow{2}{*}{ контрольна } & \multicolumn{3}{|c|}{ з токсичним ураженням $\mathrm{CCl}_{4}$} \\
\hline & & 2 доби & 7 діб & 14 діб \\
\hline МДА, мкмоль/л & $2,54 \pm 0,08$ & $7,67 \pm 0,25^{\star \star \star}$ & $10,27 \pm 0,31^{\star \star \star}$ & $5,58 \pm 0,19$ *** \\
\hline ДК, мкмоль/л & $4,14 \pm 0,18$ & $8,04 \pm 0,37^{* \star \star}$ & $6,53 \pm 0,26^{\star \star \star}$ & 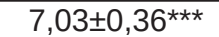 \\
\hline Каталаза, мкат/л & $0,125 \pm 0,001$ & $0,164 \pm 0,003^{\star \star \star}$ & $0,155 \pm 0,006^{\star \star \star}$ & $0,301 \pm 0,002^{\star \star \star}$ \\
\hline
\end{tabular}

Примітка. Зірочкою позначено величини, які статистично достовірно відрізняються від аналогічних показників у контрольній групі тварин (* $\left.-p<0,05 ;{ }^{*}-p<0,01 ; * \star *-p<0,001\right)$. 
лася на 4,28 \%, на 7-му - на 12,5\%, на 14-ту-на 8,0 \%. Товщина підслизової основи зросла, відповідно, на 6,4, 15,5 і 11,3 \%. Товщина м'язової оболонки в даних експериментальних умовах збільшилася на 2,5, 5,6 та 5,5 \%, а аналогічний параметр серозної оболонки товстої кишки зріс, відповідно, на 3,97, 15,1 і 11,9 \%. Виявлені зміни морфометричних параметрів були зумовлені в основному вираженими стромальними та перивазальними набряками, дистрофрічними і некробіотичними змінами епітеліоцитів, гладких міоцитів, ендотеліоцитів, дифузними клітинними інорільтраціями строми, розволокненням та дезорганізацією тканин.

Нерівномірні, диспропорційні зміни просторових характеристик слизової оболонки, підслизової основи, м'язової оболонки товстої кишки на 7-му добу токсичного гепатиту призводили до істотних порушень співвідношень між морфометричними параметрами названих структур, які адекватно відображали підслизово-м'язовий та слизово-м'язовий індекси. Так, підслизово-м'язовий індекс через 7 діб від початку досліду статистично достовірно $(p<0,05)$ зріс із 0,330 $\pm 0,009$

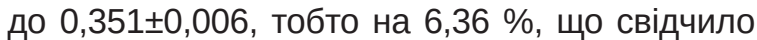
про порушення органного тканинного гомеостазу.

ВИСНОВКИ. 1. При ураженні $\mathrm{CCl}_{4}$ відбуваються суттєва активізація процесів вільнорадикального окиснення, підвищене накопичення в крові токсичних продуктів ПОЛ та послаблення фрерментативних систем антиоксидантного захисту.

2. Токсичне ураження організму чотирихлористим вуглецем призводить до значної структурної перебудови слизової оболонки, підслизової основи, м'язової та серозної оболонок товстої кишки, що супроводжується вираженими судинними розладами, альтеративними, інсрільтративними процесами і змінами морфометричних параметрів структур стінки кишки на тканинному й органному рівнях.

3. 3 огляду на отримані дані, доцільним $€$ дослідження стінки товстої кишки на всіх рівнях іiї структурної організації в нормі та при патологічних станах для розуміння процесів розвитку поліморбідних захворювань при токсичних впливах на організм.

\section{СПИСОК ЛІТЕРАТУРИ}

1. Андреєва І. В. Особливості розвитку гастроентероколопатології при портальній гіпертензії / І. В. Андреєва, І. С. Ковальова, О. А. Виноградов // Наук. вісн. Ужгород. ун-ту. Серія “Медицина". - 2011. Вип. 2 (41). - С. 9-12.

2. Gaspers L. D. Calcium signaling in liver / L. D. Gaspers, A. P. Thomas // Cell Calcium. -2005. -38, № 3-4. - P. 329-342.

3. Шульгай А. Г. Особливості моторно-евакуаторної фрункції кишки при механічній жовтяниці та після декомпресії жовчних шляхів / А. Г. Шульгай // Шпитальна хірургія. - 2005. - № 1. - С. 111-115.

4. Longstreth G. E. Functional bowel disorders / G. E. Longstreth, W. G. Thompson, W. D. Cheg // Gastroenterology. - 2006. - 130, № 5. - P. 1480-1491.

5. Маер К. Л. Гепатит и последствия гепатита / К. Л. Майер. - М. : Медицина, 2007. - 720 с.

6. De Olivera Neto J. P. Intraluminal irrigation with fibers improves mucosal inflammation and atrophy in diversion colitis / J. P. De Olivera, J. E. De AquilarNascimento // Nutricion. -2004. - 20, № 2. -P. 190-197.
7. Виявлення метаболічних порушень в організмі щурів при поєднаній дії тетрахлорметану, нітриту натрію та рентгенівського опромінення / Л. С. Фіра, О. І. Кривокульський, С. Ю. Соснієнко, Л. М. Головатюк // Екологія та ноосфрера. - 2002. - 11, № 1-2. C. 26-32.

8. Колесова О. Е. Пероксидное окисление липидов и методы определения продуктов липопероксидации в биологических средах / О. Е. Колесова, А. А. Маркин, Т. Н. Федорова // Лаб. дело. - 1984. № 9. - С. 540-546.

9. Дудин В. И. Колориметрическое определение перекиси водорода при измерении активности каталазы в крови / В. И. Дудин // Проблемы биологии продуктивных животных. - 2008. - № 2. - С. 96-99.

10. Автандилов Г. Г. Основы количественной патологической анатомии / Г. Г. Автандилов. - М. : Медицина, 2002. - 240 с.

11. Гнатюк М. С. Морфометрична оцінка особливостей ремоделювання артерій товстої кишки при токсичному гепатиті / М. С. Гнатюк, Л. М. Головатюк // Таврический мед.-биол. вестн. - 2009. -12, № 4 (48). C. 31-34. 


\section{REFERENCES}

1. Andreieva, I.V., Kovalova, I.S. \& Vynohradov, O.A. (2011). Osoblyvosti rozvytku hastroenterokolopatolohii pry portalnii hipertenzii [Peculiarities of gastroenterocolopathology development at portal hypertension]. Nauk. visn. Uzhhorod. un-tu. Seriia "Medytsyna - Scientific Journal of Uzhhorod University. Series "Medicine, 2 (41), 9-12.

2. Gaspers, L.D. \& Thomas, A.P. (2005). Calcium signaling in liver. Cell Calcium, 38 (3-4), 329-342.

3. Shulhai, A.H. (2005). Osoblyvosti motornoevakuatornoi funktsii kyshky pry mekhanichnii zhovtianytsi ta pislia dekompresii zhovchnykh shliakhiv [Morphometric assessment of arterial remodeling characteristics of the colon with toxic hepatitis]. Shpytalna khirurhiia-Hospital Surgery, (1), 111-115 [in Ukrainian].

4. Longstreth, G.E., Thompson, W.G. \& Cheg, W.D. (2006). Functional bowel disorders. Gastroenterology, 130 (5), 1480-1491.

5. Maer, K.L. Gepatit i possledstviya gepatita [Gepatitis and its consequences]. Moscow: Meditsina [in Russian].

6. De Olivera Neto, J. P. \& DeAquilar-Nascimento, J.E. (2004). Intraluminal irrigation with fibers improves mucosal inflammation and atrophy in diversion colitis. Nutricion, 20 (2), 190-197.

7. Fira, L.S., Kryvokulskyi, O.I., Sosniienko, L.M. \& Holovatiuk, L.M. (2002). Vyiavlennia metabolichnykh porushen $v$ orhanizmi shhuriv pry poiednanii dii tetrakhlormetanu, nitrytu natriiu ta renthenivskoho oprominennia [Detection of metabolic disorders in rats with combined effects of carbon tetrachloride, sodium nitrite and X-rays]. Ekolohiia ta noosfera - Ecology and Noosphere, 11 (1-2), 26-32 [in Ukrainian].

8. Kolesova, O.E., Markin, A.A. \& Fedorova, T.N. (1984). Peroksidnoe okysleniye lipidov i metody opredeleniya produktov lipoperoksidatsii $v$ biologicheskikh sredakh [Lipid peroxidation and methods of determination of lipoperoxidation products in biological surroundings]. Lab. delo. - Laboratory Work, (9), 540-546 [in Russian].

9. Dudin V.I. Kolorimetricheskoe opredelenie perekisi vodoroda pri izmerenii aktivnosti katalazy v krovi [Colorimetric determination of peroxide when evaluating catalase activity in blood]. Problemy biologii produktivnykh zhyvotnykh - Problems of Biology of Productive Animals, (2), 96-99 [in Russian].

10. Avtandilov, G.G. (2002). Osnovy kolichestvennoy patologicheskoy anatomii [Bases of quantitative and pathological anatomy]. Moscow: Meditsina [in Russian].

11. Hnatiuk, M.S. Morfometrychna otsinka osoblyvostei remodeliuvannia arterii tovstoi kyshky pry toksychnomu hepatyti [Morphometric evaluation of peculiarities of remodeling of the arteries of the colon when toxic hepatitis]. Tavricheskiy med.-biol. vestn. - Tavricheskiy Medical and Biological Journal, 12, (4), (48), 31-34 [in Ukrainian].

А. М. Пришляк, С. И. Яворская, Т. К. Головатая, Б. Я. Реминецкий ТЕРНОПОЛЬСКИЙ ГОСУДАРСТВЕННЫЙ МЕДИЦИНСКИЙ УНИВЕРСИТЕТ ИМЕНИ И. Я. ГОРБАЧЕВСКОГО

\section{ВЛИЯНИЕ ЧЕТЫРЕХХЛОРИСТОГО УГЛЕРОДА НА СОСТОЯНИЕ СВОБОДНОРАДИКАЛЬНЫХ ПРОЦЕССОВ ОРГАНИЗМА КРЫС И МОРФОЛОГИЧЕСКИЕ ИЗМЕНЕНИЯ В ТОЛСТОЙ КИШКЕ}

\section{Резюме}

Вступление. Повышенное поступление галеновых соединений в организм человека и животных может спровоцировать развитие фрункциональных нарушений и патологических изменений органов пищеварительной системы, в частности толстой кишки.

Цель исследования - оценить состояние свободнорадикальных процессов организма и морфологические изменения в толстой кишке подопытных животных при токсическом воздействии на них четыреххлористого углерода $\left(\mathrm{CCl}_{4}\right)$.

Методы исследования. Исследование выполнено на 44 белых крысах-самцах массой 180-200 2, которые были разделены на четыре группы: 1-я (контрольная) - практически здоровые животные; 2-4 крысы со смоделированным токсическим поражением $\mathrm{CCl}_{4}$. Четыреххлористый углерод вводили внутрижелудочно в виде 50,0 \% масляного раствора из расчета 0,2 мл чистого вещества на 100 г массы тела животного. Интенсивность свободнорадикальных процессов оценивали по уровню малонового диальдегида и диеновых конъюгатов, которые определяли с помощью спектрофотометрических методик, состояние антиоксидантной системы - по активности каталазы в крови. По общепринятой методике изготавливали гистологические препараты, для качественного и морфометрического анализа которых использовали систему визуального анализа изображения с применением видеокамеры Vision Color CCD u программу Inter Video Win DVR UTHSCSA Image Tool.

Результаты и обсуждение. Интоксикация животных $\mathrm{CCl}_{4}$ сопровождалась активацией свободнорадикального окисления липидов, о чем свидетельствовало увеличение в сыворотке крови крыс содер- 
жания как малонового диальдегида, так и диеновых конъюгатов в течение всего эксперимента, причем максимальную концентрацию малонового диальдегида наблюдали на 7-е сутки после отравления. Под влиянием $\mathrm{CCl}_{4}$ активность каталазы в сыворотке крови возрасла на 2-е, 7-е и 14-е сутки эксперимента в 1,3, 1,2 и 2,4 раза соответственно. Моророметрическими методами обнаружили значительную структурную перестройку слизистой оболочки, подслизистой основы, мышечной и серозной оболочек толстой кишки, сопровождающеюся выраженными сосудистыми расстройствами, альтеративными, инфильтративными процессами и изменениями морфометрических параметров структур стенки толстой кишки на тканевом и органном уровнях.

Выводы. При поражении $\mathrm{CCl}_{4}$ происходят существенная активизация процессов свободнорадикального окисления, повышенное накопление в крови токсических продуктов ПОЛ и ослабление фрерментативных систем антиоксидантной защиты. Установлена значительная структурная и морфометрическая перестройка слизистой оболочки, подслизистой основы, мышечной и серозной оболочек толстой кишки в динамике эксперимента.

КЛЮЧЕВЫЕ СЛОВА: четыреххлористый углерод; свободнорадикальное окисление; морфологические изменения; стенка толстой кишки.

A. M. Pryshlyak, S. I. Yavorska, T. K. Holovata, B. Y. Reminetskyy I. HORBACHEVSKY TERNOPIL STATE MEDICAL UNIVERSITY

\section{INFLUENCE OF CARBON TETRACHLORIDE ON THE CONDITION OF FREE RADICAL PROCESSES OF RATS' ORGANISM AND MORPHOLOGICAL CHANGES IN THE COLON}

\section{Summary}

Introduction. Increased admission of herbal compounds in organism of humans and animals can trigger the development of functional disorders and pathological changes of the digestive system and in particular the colon.

The aim of the study - to evaluate the state of free radical processes and morphological changes in the colon with toxic experimental animals exposed by carbon tetrachloride.

Research Methods. The study was performed on 44 white male rats weighing 180-200 g which were divided into 4 groups: group 1 - control (almost healthy animals); group 2-4 - rats with simulated toxic lesion by $\mathrm{CCl}_{4}$. Intragastric $\mathrm{CCl}_{4}$ was administered in $50.0 \%$ oil solution at a rate of $0.2 \mathrm{ml}$ of pure substance per $100 \mathrm{~g}$ of body weight. The intensity of free radical processes evaluated with the level of malondialdehyde and diene conjugates, determined using spectrophotometric techniques; antioxidant system - with the activity of catalase in blood. According to the conventional method histological preparations were made. For qualitative and morphometric analysis system of a visual analysis of images using camera Vision Color CCD program and Inter Video Win DVR UTHSCSA Image Tool were used.

Results and Discussion. The results shows that animals carbon tetrachloride intoxication is accompanied by activation of free radical oxidation of lipids, as evidenced by the increase in blood serum of animal content as malondialdehyde (MDA) and diene conjugates (DC) throughout the experiment, with the maximum concentration observed in malondialdehyde 7 days after poisoning. Under the influence of $\mathrm{CCl}_{4}$ catalase activity increases in serum at the second, seventh and fourteenth days of the experiment in 1.3, 1.2 and 2.4 times respectively. Morphometric techniques revealed a significant restructuring of the mucosa, submucosa, muscular layer and serous membrane of the colon, accompanied by severe vascular disorders of alterative, infiltrative processes and changes of morphometric parameters of the colon's wall structures at tissue and organ levels.

Conclusions. In the case of $\mathrm{CCl}_{4}$ damage, the processes of free radical oxidation take place, the accumulation of toxic products of lipid peroxidation in the blood and the weakening of the enzyme system of antioxidant protection occur. A significant structural and morphometric reconstruction of the mucosa, submucosa, muscular and serous membranes of the colon has been established.

KEY WORDS: carbon tetrachloride; free radical oxidation; the wall of the colon.

Отримано 15.05.17

Адреса для листування: Б. Я. Ремінецький, Тернопільський державний медичний університет імені І. Я. Горбачевського, майдан Волі, 1, Тернопіль, 46001, Україна, e-mail: reminets@tdmu.edu.ua. 